\title{
AiMT
}

Advances in Military Technology

Vol. 12, No. 2 (2017), pp. 177-184

ISSN 1802-2308, eISSN 2533-4123

DOI 10.3849/aimt.01162

\section{Body Anthropometric Study of Malaysian Security Personnel}

\author{
N.W.N. Fatimah, A.J. Khalid* and M.S. Risby \\ Department of Mechanical Engineering, Faculty of Engineering, \\ National Defence University of Malaysia, Malaysia
}

The manuscript was received on 20 October 2016 and was accepted after revision for publication on 1 October 2017.

\begin{abstract}
:
The case study presents a collection of anthropometric data obtained from security agency personnel who worked at the National Defence University of Malaysia in 2011. The study involved 450 male respondents ranging from 21 to 57 years old. Anthropometric dimensions of chest, shoulder, waist, hip, and neck circumferences were measured, and one-way ANOVA was performed to determine significant difference for selected parameters by age group. Statistical results showed a significant correlation between body measurements (chest, waist, hip, and neck circumferences) and age group.
\end{abstract}

\section{Keywords:}

military, ergonomics, Asian, clothing, equipment

\section{Introduction}

Studies on ergonomics suggest that individuals differ in terms of shape, attribute, size, strength, work capacity, and endurance. A basic understanding of human physiology and anatomy can help researchers resolve ergonomics-related problems and prevent harm or injury in the workplace [1]. For example, many security personnel wear protective gears to guard themselves while on duty. A body armour vest is a piece of protective clothing that prevents firearm injury.

In the field of defence, a common gear consists of a ballistic-resistant body armour vest, either with or without ceramic insert plates, and a ballistic helmet [2]. However, body armour vests, ceramic insert plates, and helmets are manufactured globally in many sizes and variants, and hence may not be ergonomically fit for

\footnotetext{
* Corresponding author: Department of Mechanical Engineering, National Defence University of Malaysia, Kem Sg Besi, Kuala Lumpur, Malaysia.

Phone: +603-90 5134 00,+603-90 5134 72,e-mail: khalid@upnm.edu.my
} 
individual security personnel. Thus, the current challenge is to identify and upgrade the ergonomic properties of equipment and clothing, and the main task is to improve the protection coverage and safety level of equipment and clothing while keeping their overall weights to a minimum. Design problems often deal with inconsistencies in human anthropometrics, or those aspects related to the shape, material, and weight of body armour products. Therefore, designers need to consider anthropometric measurements of different body types.

In Malaysia, most armour designers refer to foreign standards for body protective gears. However, these standards are likely not suitable for Malaysian consumers who come from different races and ethnicities. Previous studies have proven that Asian body standards are smaller than the Western standards [3-5]. In addition, data reported by previous works only estimate the body size of Malaysian security agency personnel (e.g., armed forces, police, firefighters, customs, and maritime staff). Therefore, a much detailed Malaysian anthropometric standard is essential prior to designing the best and most comfortable protective clothing for Malaysian security agencies. The present study assumed that the clothing will be used by Malaysian personnel to protect their bodies, maximize clothing usability, minimize fatigue, and resolve comfortability issues.

Anthropometric data are commonly gathered for weight, stature, height, body mass index (BMI), and body fat analyses [1-8], but studies on body circumference, especially chest circumference that is vital in the design of body clothing and armours, are limited. Vaidya et al. [9] recorded anthropometric measurements of 902 healthy Indian armed forces personnel aged $28 \div 52$ years. Their study also compared different anthropometric parameters (e.g. obesity indices), as well as mean, median, standard deviation, and percentile values. Anthropometric measurements for weight, height, waist, and hip circumferences were also gathered from respondents. The weights of respondents ranged from $49 \mathrm{~kg}$ to $96.80 \mathrm{~kg}$ with mean value of $70.16 \mathrm{~kg}$. Except for height, all anthropometric measurements such as BMI, waist-hip ratio, and waist circumference increased incrementally with age. The present study takes a similar approach in gathering the body measurements of Malaysian security agency personnel, particularly their chest, shoulder, waist, hip and neck circumferences.

\section{Methodology}

\subsection{Sampling Size}

The case study involved male security personnel who worked at the National Defence University of Malaysia (NDUM) in 2011. Respondent characteristics and sampling size were adopted from previous works, i.e., Deros et al. [5] who studied 226 respondents and Karmegam et al. [11] who collected anthropometric data from 300 respondents.

For the present study, anthropometric measurements were conducted by professional tailors, and data used for analysis were randomly selected with permission from Usahawan PSE Sdn Bhd. The study involved 450 male respondents, and their ages varied between 20 and 57 years. Age was subdivided into five-year intervals (i.e., $20 \div 25,26 \div 30,31 \div 35,36 \div 40,41 \div 45,46 \div 50$, and $51+$ years), and age distribution was normalized by frequency analysis. Fig. 1 shows the summary of the age distribution of respondents. 


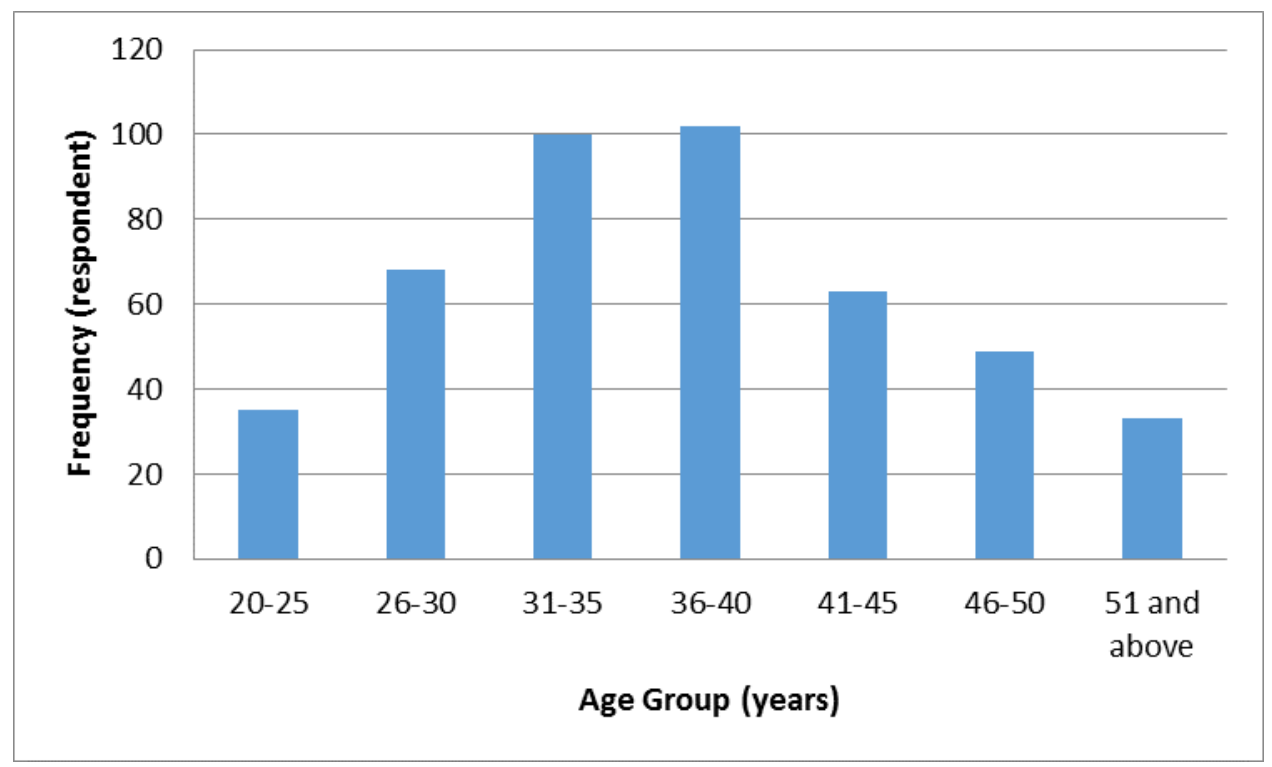

Fig. 1 Normal age distribution of Malaysian security agency personnel working at NDUM in 2011

\subsection{Measuring Equipment}

Yasuto et al. [4], Mokdad and Al-Ansari [6], and Karmegam et al. [11] have reported that traditional methods, such as using measuring tapes, generate the same consistent and precise data as those obtained using high-technology methods (e.g., 3D scanner). Other researchers have used high-technology measuring tools, such as the Harpenden -Skinfold branded calliper, standard anthropometric rod, portable weighing machine, and digital calliper steel tape. In this study, a traditional anthropometric tool (i.e., measuring tapes that are simple and less expensive to use) was used for data collection.

\subsection{Anthropometric Parameters}

Hu et al. [7], Pheasant [8], and Roebuck et al. [9] have reported that body anthropometry might need over 300 parameters or dimensions to cover the whole human body. For this study, to ensure consistency in measurement, the anthropometric circumference values of the chests, shoulders, waists, hips, and necks of respondents were recorded by professional tailors from Usahawan PSE Sdn Bhd. Measurements were repeated thrice, and data were averaged into their single values. During measurement, respondents were required to wear light clothing, as shown in Fig. 2.

\subsection{Statistical Analysis}

SPSS software version 16.0 was used to determine the statistical outcomes of the measurements, which is similar to the approach of Karmegam et al. [11]. Descriptive analysis was performed to distribute the means, standard deviations, and percentiles $\left(95^{\text {th }}, 50^{\text {th }}\right.$ and $\left.5^{\text {th }}\right)$ of the measurements [11-13]. Statistical significance was set at 
$p$-level of $<0.05$. One-way ANOVA, a statistical test, was conducted to establish significant difference between age group and the selected body measurements (i.e., mean values of chest, shoulder, waist, hip, and neck circumferences).

ANOVA tests apply the concept of variability, which can be classified into two: random variability, which does not establish significant influence of a given data, and systematic variability, which attempts to find significant datasets. For the correlation, regression was employed to establish the ratio-interval variable relationship in the present study; that is, a single dependent variable is regressed with an independent variable [12-14].

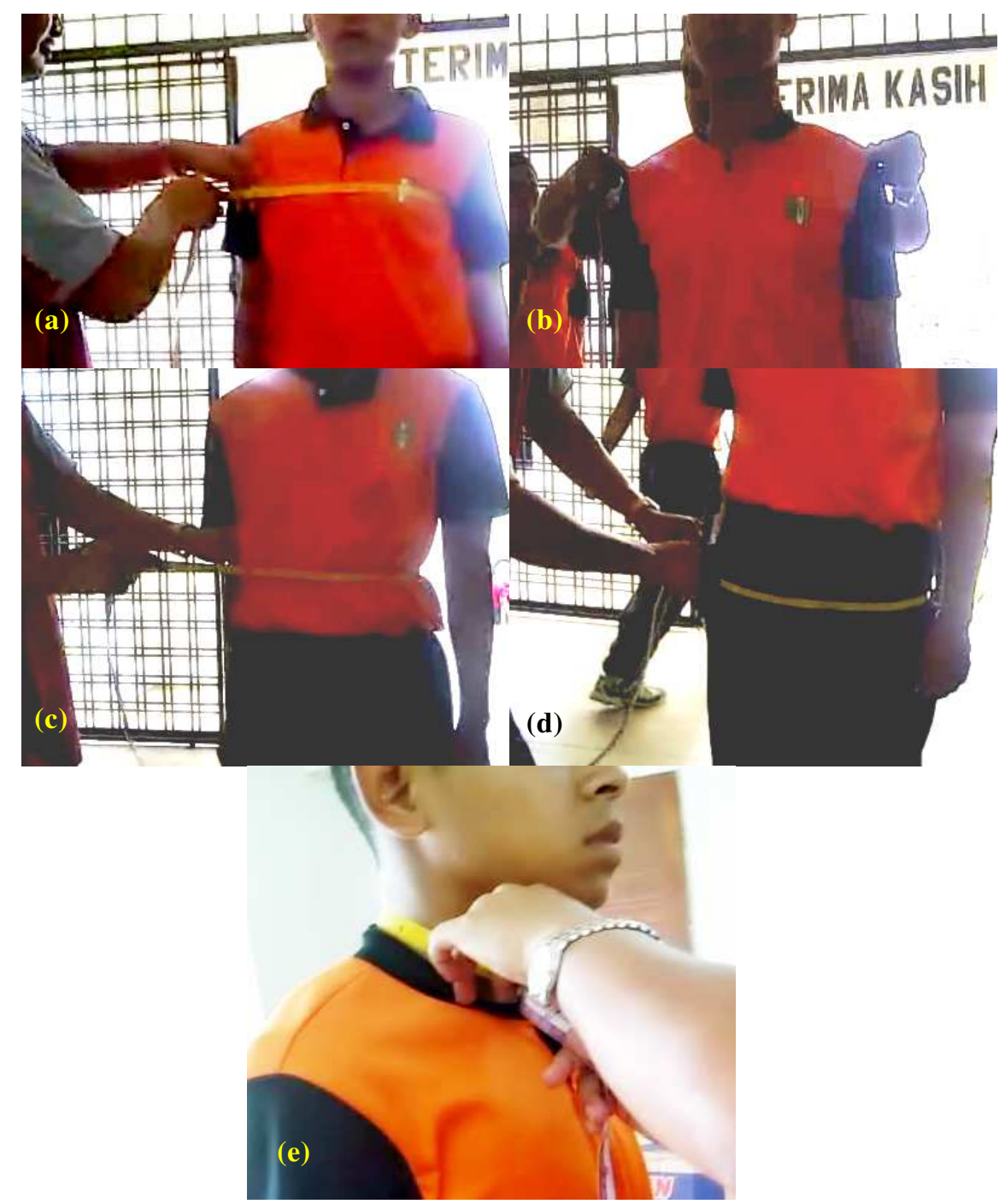

Fig. 2 Measurement of anthropometric parameters: (a) chest, (b) shoulder, (c) waist, (d) hip, and (e) neck 
One-way ANOVA is generally employed to determine whether mean values significantly differ for one or more datasets or groups. In the present study, one-way ANOVA was used to establish significant difference in the body anthropometric measurements of Malaysian security agency personnel belonging to different age groups [12, 13]. Chest, shoulder, waist, hip, and neck circumferences were identified as dependent variables, while age group was set as the independent variable. Results are used to analyze the significant differences [4, 14].

\section{Results and Discussion}

\subsection{Data Screening}

This study used the five variables of chest circumference, shoulder circumference, waist circumference, hip circumference, and neck circumference as basis for analysis. Skewness was less than \pm 2.0 and Kurtosis value was less than \pm 5.0 . The variables satisfactorily met the assumption requirements of univariate normality (Tab. 1). Statistical analysis of the measurements showed similar trends (median), which is similar to the works of Chuan et al. [15] and Manandhar et al. [16]. The present study further assumed that the Malaysian population, which are composed mostly of Malay, Javanese, Chinese, and Indian ethnic groups, shares similar anthropometric attributes and characteristics as those of other ethnic groups from neighbouring, countries in the Southeast Asian region.

Tab. 1 Results of normal distribution test

\begin{tabular}{|c|c|c|c|c|c|c|c|c|c|}
\hline \multirow[t]{2}{*}{ Parameters } & \multirow{2}{*}{$\begin{array}{c}\mathbf{N} \\
\text { Sample }\end{array}$} & \multirow[t]{2}{*}{ Min } & \multirow[t]{2}{*}{ Max } & \multirow[t]{2}{*}{ Mean } & \multirow{2}{*}{$\begin{array}{c}\text { Std } \\
\text { Deviation }\end{array}$} & \multicolumn{2}{|c|}{ Skewness } & \multicolumn{2}{|c|}{ Kurtosis } \\
\hline & & & & & & & $\begin{array}{c}\text { Std } \\
\text { Error }\end{array}$ & & $\begin{array}{c}\text { Std } \\
\text { Error }\end{array}$ \\
\hline $\begin{array}{l}\text { Chest } \\
\text { Circumference }\end{array}$ & 450 & 24.500 & 50.500 & 39.012 & 2.87410 & 0.018 & 0.115 & 2.021 & 0.230 \\
\hline $\begin{array}{l}\text { Shoulder } \\
\text { Circumference }\end{array}$ & 450 & 14.500 & 22.000 & 18.049 & 1.03180 & -0.037 & 0.115 & 0.589 & 0.230 \\
\hline $\begin{array}{l}\text { Waist } \\
\text { Circumference }\end{array}$ & 450 & 19.500 & 48.500 & 35.361 & 3.65230 & -0.165 & 0.115 & 1.058 & 0.230 \\
\hline $\begin{array}{l}\text { Hip } \\
\text { Circumference }\end{array}$ & 450 & 27.000 & 53.000 & 40.727 & 2.71990 & -0.084 & 0.115 & 2.746 & 0.230 \\
\hline $\begin{array}{l}\text { Neck } \\
\text { Circumference }\end{array}$ & 450 & 12.500 & 19.000 & 15.829 & 0.85863 & 0.239 & 0.115 & 0.813 & 0.230 \\
\hline
\end{tabular}

\subsection{One-way ANOVA}

ANOVA was used to examine significant correlation of the selected body measurements to age group (Tab. 2). Significant differences were observed for chest circumference $(F=8.494, p<0.05)$, waist circumference $(F=13.095, p<0.05)$, hip circumference $(F=4.614, p<0.05)$, and neck circumference $(F=8.305, p<0.05)$. Chest, waist, hip, and neck circumferences increased incrementally with age group. However, a different trend was observed for shoulder circumference $(F=1.654$, $p>0.05$ ), which suggest that this variable was not correlated to age group.

As shown in Tab. 3, the mean anthropometric values increased with age. The mean values of waist, chest, hip, and neck circumferences differed significantly by age group ( $p<0.05$ for all comparisons). However, age-related differences were not significant for the shoulder circumference $(p=0.122)$. 
Tab. 2 Results of one-way ANOVA

\begin{tabular}{|l|l|r|r|r|c|}
\hline Variable & \multicolumn{1}{|c|}{$\begin{array}{c}\text { Sum of } \\
\text { Squares }\end{array}$} & df & $\begin{array}{c}\text { Mean } \\
\text { Square }\end{array}$ & F \\
\hline Chest & Between Groups & 382.682 & 6 & 63.780 & $8.494^{*}$ \\
Circumference & Within Groups & 3326.501 & 443 & 7.509 & \\
& Total & 3709.183 & 449 & & \\
Choulder & Between Groups & 10.475 & 6 & 1.746 & 1.654 \\
& Within Groups & 467.612 & 443 & 1.056 & \\
& Total & 478.087 & 449 & & \\
\hline Waist & Between Groups & 902.265 & 6 & 150.377 & $13.095^{*}$ \\
\hline Hip & Within Groups & 5087.312 & 443 & 11.484 & \\
Circumference & Total & 5989.576 & 449 & & \\
& Wetween Groups & 195.363 & 6 & 32.560 & $4.614^{*}$ \\
& Total Groups & 3126.466 & 443 & 7.057 & \\
Circumference & Between Groups & 3321.829 & 449 & & \\
& Within Groups & 297.468 & 6 & 5.578 & $8.305^{*}$ \\
& Total & 331.023 & 449 & 0.672 & \\
\hline
\end{tabular}

Note: *means significance at $p<0.05$

\section{Conclusion}

The study was conducted to provide an estimation of anthropometric information from Malaysian male security agency personnel aged 20 years and above. Results can be used for the future ergonomic design of security equipment. Five anthropometric parameters or dimensions were categorized by their mean, variation coefficient, standard deviation, and percentile values. Nonetheless, respondent sample size is still small compared with the size of Malaysian security personnel serving in government-related agencies. Respondents were also randomly selected based on their availability and convenience. Data analysis suggests differences in body dimension for different age groups. Findings indicate that body circumferences increase with age; however, shoulder circumference was not correlated to age group. Consequently, on the basis of ergonomic principles, anthropometrics should be applied in the design of protective gears for use in defence and in the workplace. In Malaysia, manufacturers can use the data from the present study as reference when designing appropriate and stress-free equipment that is conducive for the workplace. However, this study is not conclusive because it provides only selective anthropometric parameters. Thus, further research and data collection with more parameters are needed.

\section{Acknowledgement}

The authors wish to acknowledge the research grant provided by Fundamental Research Grant Scheme (FRGS) from the Malaysian Ministry of Higher Education that lead to realization of this work. 
Tab. 3 Anthropometric measurements of military personnel by age group

\begin{tabular}{|l|c|c|c|c|}
\hline \multirow{2}{*}{ Measurements } & \multicolumn{2}{|c|}{ Men $(\boldsymbol{n}=\mathbf{4 5 0})$} & \multirow{2}{*}{$\boldsymbol{F}$} & \multirow{2}{*}{$\boldsymbol{p}$} \\
\cline { 2 - 3 } Chest circumference [inch] & Mean & SD & & \\
$20 \div 25$ [years] & 36.6857 & 0.302014 & & \\
$26 \div 30$ [years] & 38.0074 & 0.333341 & & \\
$31 \div 35$ [years] & 39.3150 & 0.340799 & \multirow{2}{*}{$8.494^{*}$} & $0.000^{*}$ \\
$36 \div 40$ [years] & 38.9755 & 0.296421 & & \\
$41 \div 45$ [years] & 39.5635 & 0.248522 & & \\
$46 \div 50$ [years] & 40.0204 & 0.343476 & & \\
51 and above [years] & 40.1970 & 0.361460 & & \\
\hline Shoulder circumference [inch] & & & & \\
$20 \div 25$ [years] & 17.7571 & 0.168871 & & \\
$26 \div 30$ [years] & 17.7978 & 0.119932 & & \\
$31 \div 35$ [years] & 18.1325 & 0.121046 & \multirow{2}{*}{1.654} & 0.113 \\
$36 \div 40$ [years] & 18.0613 & 0.104815 & & \\
$41 \div 45$ [years] & 18.1944 & 0.104685 & & \\
$46 \div 50$ [years] & 18.1122 & 0.135617 & & \\
51 and above [years] & 18.2197 & 0.150267 & & \\
\hline Waist circumference [inch] & & & & \\
$20 \div 25$ [years] & 32.1571 & 0.392563 & & \\
$26 \div 30$ [years] & 33.9265 & 0.412740 & & \\
$31 \div 35$ [years] & 35.4150 & 0.414635 & \multirow{2}{*}{$13.095 *$} & $0.000^{*}$ \\
$36 \div 40$ [years] & 35.2672 & 0.353043 & & \\
$41 \div 45$ [years] & 36.2222 & 0.354327 & & \\
$46 \div 50$ [years] & 36.7143 & 0.395755 & & \\
51 and above [years] & 38.1970 & 0.517652 & & \\
\hline Hip circumference [inch] & & & & \\
$20 \div 25$ [years] & 39.1571 & 0.450850 & & \\
$26 \div 30$ [years] & 40.2794 & 0.312243 & & \\
$31 \div 35$ [years] & 41.2550 & 0.323452 & \multirow{2}{*}{$4.614^{*}$} & $0.000^{*}$ \\
$36 \div 40$ [years] & 40.3088 & 0.274635 & & \\
$41 \div 45$ [years] & 41.0119 & 0.268482 & & \\
$46 \div 50$ [years] & 41.2347 & 0.318139 & & \\
51 and above [years] & 41.7121 & 0.319824 & & \\
\hline Neck circumference [inch] & & & & \\
$20 \div 25$ [years] & 15.1500 & 0.108562 & & \\
$26 \div 30$ [years] & 15.5331 & 0.086689 & & \\
$31 \div 35$ [years] & 15.8350 & 0.093624 & \multirow{2}{*}{$8.305^{*}$} & \\
$36 \div 40$ [years] & 15.8971 & 0.086268 & & \\
$41 \div 45$ [years] & & & \\
$46 \div 50$ [years] & & & \\
51 and above [years] & & & \\
\hline
\end{tabular}

\section{References}

[1] LEHTO, M.R. and LANDRY, S.J. Human System: Chapter Two, Introduction to Human Factors and Ergonomics for Engineers. $2^{\text {nd }}$ edition, CRC Press, 2013. 
[2] PELEG, K., RIVKIND, A and DANIEL, L. Does Body Armour Protect from Firearm Injuries? American College of Surgeons, 2006, vol. 202, no. 4, p. 643-648.

[3] KAGAWA, M., BINNS, C.W. and HILLS, A.P. Body Composition and Anthropometry in Japanese and Australian Caucasian Males and Japanese Females. Asia Pacific Journal of Clinical Nutrition, 2007, vol. 16 no. 1, p. 31-36.

[4] YASUTO, N. and VINCENT, N. Anthropometric Comparison between Japanese and Caucasian American Male University Students. Applied Human Science: Journal of Physiological Anthropology, 1998, vol. 18, no. 1, p. 9-11.

[5] DEROS, B.M., MOHAMAD, D., ISMAIL, A.R. and NAZREE, M.N.M. Application of Malaysian Anthropometric Data in Home Furniture Design. National Symposium on Advancements in Ergonomics and Safety (ERGOSYM2009). Perlis, Malaysia, 2009, p. 68-71.

[6] MOKDAD, M. and AL-ANSARI, M. Anthropometrics for the Design of Bahraini School Furniture. International Journal of Industrial Ergonomics, 2009, vol. 39, no. 5 , p. 1-8.

[7] HU, H., LIA, Z., YANA, J., WANGA, X., XIAOB, H., DUANA, J. and ZHENGA, L. Anthropometric Measurement of the Chinese Elderly Living in the Beijing Area. International Journal of Industrial Ergonomics, 2007, vol. 37, p. 303-311.

[8] PHEASANT, S. Bodyspace: Anthropometry. Ergonomics and Design. Taylor and Francis, 1986, vol. 31.

[9] ROEBUCK, J.A., KROEMER, K.H.E. and THOMPSON, W.G. Engineering Anthropometric Methods. $2^{\text {nd }}$ edition, New York: Wiley, 1975.

[10] VAIDYA, R., BHALWAR, R. and BOBDEY, S. Anthropometric Parameters of Armed Forces Personnel. Med J Armed Forces India. 2009, vol. 65, no. 4, p. 313-318.

[11] KARMEGAM, K. et al. Anthropometric Study Among Adults of Different Ethnicity in Malaysia. International Journal of the Physical Sciences. 2011, vol. 6 , no. 4 , p. 777-788.

[12] HAIR, J.F.,Jr., BLACK, W.C., BABIN, B.J., ANDERSON, R.E. and TATHAM, R.L. Multivariate data analysis. $6^{\text {th }}$ edition, New Jersey: Prentice Hall, 2006.

[13] YAACOB, M.R. SPSS for Business and Social Science Students: Version 14 for Windows. Kota Bharu: Pustaka Aman Press, 2008.

[14] CURRAN, P.J., WEST, S.G. and FINCH, G.F. The Robustness of Test Statistics to Non-normality and Specification Error in Confirmatory Factor Analysis. Psychological Methods, 1996, vol. 1, p. 16-29.

[15] CHUAN, T.K., Hartono, M. and Kumar, N. Anthropometry of the Singaporean and Indonesian Populations, International Journal of Industrial Ergonomics, Vol. 40, no. 6, 2010, p. 757-766.

[16] MANANDHAR, M.C., ANKLESARIAZ, P.S. and ISMAIL, S.J. Weight, Skinfolds and Circumference Characteristics of Poor Elderly People in Mumbai, India. Asia Pacific Journal of Clinical Nutrition, 1997, vol. 6, no. 3, p. 191-199. 